\title{
EVALUASI RASIONALITAS PENGGUNAAN ANTIBIOTIK DENGAN \\ PENDEKATAN METODE GYSSENS TERHADAP LUARAN KLINIS PASIEN BALITA PENDERITA PNEUMONIA DI RSUD KOTA BOGOR (EVALUATION OF RATIONALITY OF ANTIBIOTIC USE IN TODDLER WITH PNEUMONIA USING GYSSEN METHODS AT BOGOR CITY REGIONAL HOSPITAL)
}

\author{
Naifah Luthfiyah Putri ${ }^{1}$, Hany Yusmaini ${ }^{2}$, Sugeng Wiyono ${ }^{3}$ \\ ${ }^{1}$ Program Studi Sarjana Kedokteran, Fakultas Kedokteran UPN “Veteran” Jakarta \\ ${ }^{2}$ Departemen Farmakologi, Fakultas Kedokteran UPN "Veteran" Jakarta \\ ${ }^{3}$ Jurusan Gizi, Politeknik Kesehatan Kementerian Kesehatan Jakarta II \\ Email korespondensi: hany.yusmaini@gmail.com
}

\begin{abstract}
ABSTRAK
Pneumonia merupakan penyebab terbanyak kematian balita di dunia terutama di Indonesia. Insidensi penyakit pneumonia di Indonesia mengalami peningkatan dari $63,45 \%$ pada tahun 2015 menjadi 65,27\% pada tahun 2016. Pada tahun 2017, pneumonia termasuk ke dalam 10 besar penyakit terbanyak di Instalasi Rawat Inap RSUD Kota Bogor. Kejadian resistensi antibiotik pada penyakit infeksi seperti pneumonia telah menjadi masalah global. Salah satu cara untuk mengatasi kejadian resistensi antibiotik adalah dengan melakukan evaluasi rasionalitas penggunaan antibiotik. Tujuan penelitian adalah mengevaluasi rasionalitas penggunaan antibiotik pada pasien pneumonia balita di RSUD Kota Bogor. Penelitian ini merupakan penelitian analitik dengan desain cross-sectional. Data penelitian diambil dari 77 rekam medis pasien pneumonia balita yang memenuhi kriteria inklusi dan dirawat inap di RSUD Kota Bogor Tahun 2017. Penelitian ini mengevaluasi rasionalitas penggunaan antibiotik dengan menggunakan metode Gyssens dan melihat luaran klinis berupa suhu tubuh pada 48-72 jam setelah penggunaan antibiotik. Hasil penelitian menunjukkan bahwa bahwa penggunaan antibiotik secara rasional sebanyak 51,9\% pasien memenuhi seluruh kriteria Gyssens. Penggunaan antibiotik rasional akan memberikan optimalisasi terapi sehingga luaran klinis yang dihasilkan baik. Terdapat hubungan antara penggunaan antibiotik dengan luaran klinis pada pasien rawat inap balita penderita pneumonia di RSUD Kota Bogor Tahun 2017.
\end{abstract}

Kata kunci : metode Gyssens, pneumonia, rasionalitas penggunaan antibiotik 
Putri NL: Evaluasi Rasionalitas Penggunaan...

\section{ABSTRACT}

Pneumonia is the most common cause of mortality in toddler in the world, mainly in Indonesia. The incidence rates of pneumonia in Indonesia is 63,45\% in 2015 and rises to 65,27\% in 2016. Based on data of Bogor City Regional Hospital's medical records in 2017, pneumonia is included in the 10 most major diseases in inpatient department. Antibiotic resistance has become major global health problem. One of the strategies to overcome antibiotic resistance is to evaluate the rationality of antibiotic use. The evaluation of rationality of antibiotic use in toddler with pneumonia at Bogor City Regional Hospital has never been performed. This study was an analitical cross sectional study that are collected at one point in time based on medical records of toddler inpatients with pneumonia in Bogor City Regional Hospital in 2017, with 77 samples. This study evaluates the rationality of antibiotic use using the Gyssens method and looks at clinical outcomes in the form of body temperature at 48-72 hours after antibiotic use. The results of this study were $51.9 \%$ rational use, meaning that the use of antibiotics in 51.9\% of patients had fulfilled all Gyssens criteria. Rational use of antibiotics will provide optimal antibiotic therapy so that the clinical outcomes produced are also optimal or good. Use of antibiotics in toddler inpatients with pneumonia is significantly associated with clinical outcomes.

Keywords: pneumonia, antibiotic use rationality, Gyssens method

\section{PENDAHULUAN}

Infeksi Saluran Pernafasan Akut (ISPA) merupakan penyebab terpenting morbiditas dan mortalitas pada anak. Berdasarkan data Kementerian Kesehatan Republik Indonesia tahun 2014, pneumonia adalah penyebab paling banyak kematian balita di dunia terutama di Indonesia. ${ }^{1}$ Populasi yang termasuk ke dalam kelompok rentan terhadap pneumonia adalah anak berusia kurang dari 2 tahun, usia lanjut lebih dari 65 tahun dan orang yang memiliki masalah kesehatan. ${ }^{2}$
Menurut Riset Kesehatan Dasar Tahun 2013 didapatkan insidensi terjadinya pneumonia di Indonesia sebesar $1,8 \%$ dengan prevalensi sebesar 4,5\%. Pada tahun 2014, angka cakupan penemuan pneumonia balita yaitu sebesar 29,47 dan meningkat menjadi 65,27\% pada tahun 2016. Menurut data di Profil Kesehatan Provinsi Jawa Barat tahun 2015, jumlah kasus pneumonia pada balita yang ditemukan dan ditangani di Jawa Barat sebesar 166.888 kasus. Angka tersebut 
Putri NL: Evaluasi Rasionalitas Penggunaan...

mengalami penurunan pada tahun 2016 sebesar 152.090 kasus. $^{3}$

Salah satu upaya untuk menurunkan angka kematian akibat pneumonia adalah pemberian antibiotik secara tepat. Namun seringkali dijumpai penggunaan antibiotik tidak tepat pemberian. ${ }^{4}$ Kejadian resistensi antibiotik menjadi masalah di berbagai negara di dunia dan membutuhkan perhatian khusus. Salah satu cara untuk mengatasi kejadian resistensi antibiotik adalah dengan menggunakan antibiotik secara rasional, melakukan monitoring dan evaluasi penggunaan antibiotik dengan dua metode yaitu secara kuantitatif dan kualitatif. Evaluasi antibiotik secara kualitatif dilakukan dengan menilai ketepatan penggunaan antibiotik dengan menggunakan alur Gyssens. Paramater yang dinilai dari metode Gyssens yaitu indikasi, pemilihan antibiotik berdasarkan efektivitas, toksisitas, spektrum, harga, durasi pengobatan, ketepatan dosis, interval dan rute pemberian, serta waktu pemberian. ${ }^{4}$ Setelah 48-72 jam pemberian antibiotik dan telah dilakukan evaluasi, pasien akan dinilai luaran klinis (outcome) berupa suhu tubuh pasien. Penggunaan antibiotik yang rasional akan menghasilkan outcome yang baik berupa suhu tubuh pasien kembali normal.

Berdasarkan tingginya angka penggunaan antibiotik yang tidak rasional, peneliti tertarik untuk melakukan penelitian mengenai evaluasi rasionalitas penggunaan antibiotik dengan pendekatan metode Gyssens pada pasien rawat inap balita penderita pneumonia di Rumah Sakit Umum Daerah Kota Bogor.

\section{METODE PENELITIAN}

\section{Jenis Penelitian}

Jenis penelitian ini merupakan penelitian cross-sectional analitik berdasarkan data rekam medis di RSUD Kota Bogor. Penelitian ini mengevaluasi rasionalitas penggunaan antibiotik pada pasien rawat inap balita penderita pneumonia dengan menggunakan Metode Gyssens. Kemudian, penelitian ini mengumpulkan kelompok pasien yang penggunaaan antibiotiknya sudah rasional dan tidak rasional. Luaran klinis (outcome) berupa suhu tubuh setiap 48-72 jam setelah penggunaan antibiotik pada dua kelompok tersebut akan dievaluasi.

\section{Populasi dan Sampel}

Populasi pada penelitian ini adalah seluruh pasien pneumonia komunitas balita yang dirawat inap di RSUD Kota Bogor Tahun 2017.

Sampel pada penelitian ini adalah pasien pneumonia komunitas balita yang dirawat inap di RSUD Kota Bogor Tahun 2017 yang memenuhi kriteria yaitu pasien dengan data rekam medik yang lengkap, berusia 0-5 tahun, pasien yang pada saat 
Putri NL: Evaluasi Rasionalitas Penggunaan...

kondisi keluar rumah sakit dalam keadaan membaik dan diijinkan pulang, tidak mengalami komplikasi, dan tidak didiagnosis utama penyakit lain.

\section{Pengambilan Sampel}

Pengambilan sampel menggunakan probability sampling dengan simple random sampling, mengambil sampel anggota populasi secara acak tanpa memperhatikan strata yang ada dalam populasi.

\section{HASIL DAN PEMBAHASAN}

\section{Gambaran Umum Subjek Penelitian}

Subjek pada penelitian ini adalah pasien rawat inap balita penderita pneumonia di RSUD Kota Bogor Tahun 2017. Dari 77 pasien rawat inap balita penderita pneumonia di RSUD Kota Bogor Tahun 2017, terdapat 7 jenis antibiotik yang digunakan (pemberian tunggal \& kombinasi). Pada penelitian ini, subjek penelitian akan dinilai rasionalitas penggunaan antibiotik yang diberikan dan akan dilihat luaran klinis berupa suhu tubuh pada 48-72 jam setelah pemberian antibiotik. $^{4}$

Tabel 1 Distribusi Usia Pasien Rawat Inap Balita Penderita Pneumonia Di RSUD Kota Bogor Tahun 2017

\begin{tabular}{lcc}
\hline \multicolumn{1}{c}{ Usia } & n & \% \\
\hline 0-1 Bulan & 3 & 3,9 \\
2-12 Bulan & 36 & 46,7 \\
1-5 Tahun & 38 & 49,4 \\
Total & $\mathbf{7 7}$ & $\mathbf{1 0 0}$ \\
\hline
\end{tabular}

Sumber : Data Sekunder, 2019

\section{Analisis Univariat}

Subjek penelitian sebagian besar adalah pasien berusia 1-5 tahun sebesar 49,4\%, sesuai dengan Profil Kesehatan Indonesia Tahun 2016 yang menyebutkan bahwa populasi yang termasuk ke dalam kelompok rentan terhadap penyakit pneumonia antara lain usia kurang dari 5 tahun (balita), usia lebih dari 65 tahun, dan orang yang mempunyai masalah kesehatan. ${ }^{9}$ Besarnya jumlah pasien balita penderita pneumonia yang berusia 1-5 tahun dapat disebabkan karena aktivitas anak yang mulai meningkat dan sistem imunitas yang belum sempurna sehingga anak berusia 1-5 tahun rentan terkena penyakit pneumonia. ${ }^{10-11}$ Makanan yang dikonsumsi oleh anak berusia 1-5 tahun juga mempengaruhi terhadap kejadian pneumonia, mengingat balita di atas dua 
Putri NL: Evaluasi Rasionalitas Penggunaan...

tahun sudah tidak mendapatkan ASI dan kebutuhan gizi utama berasal dari makanan yang dikonsumsi. ${ }^{12}$

Tabel 2. Distribusi Jenis Kelamin Pasien Rawat Inap Balita Penderita Pneumonia di RSUD Kota Bogor Tahun 2017

\begin{tabular}{lcc}
\hline \multicolumn{1}{c}{ Jenis Kelamin } & n & \% \\
\hline Laki-Laki & 47 & 61 \\
Perempuan & 30 & 39 \\
Total & $\mathbf{7 7}$ & $\mathbf{1 0 0}$ \\
Sumber : Data Sekunder,2019 & &
\end{tabular}

Sesuai Tabel 2, sebagian besar subyek adalah pasien berjenis kelamin laki-laki (61\%). Banyaknya pasien pneumonia balita yang berjenis kelamin laki-laki didukung dengan data epidemiologi dari British Thoracic Society (BTS) yang menunjukkan sebagian besar pasien balita penderita pneumonia berjenis kelamin laki-laki. ${ }^{7}$ Laki-laki lebih rentan terkena penyakit pada bagian saluran pernafasan disebabkan karena perbedaan fisiologi saluran pernafasan antar jenis kelamin. Pada pasien balita laki-laki pertumbuhan sel tubuhnya lebih lambat dibandingkan dengan balita perempuan. Keterlambatan kematangan organ paru pada balita laki-laki dapat menyebabkan pasien balita laki-laki lebih rentan terkena penyakit infeksi pada organ paru. ${ }^{11}$

Tabel 3. Distribusi Lama Rawat Inap Pasien Rawat Inap Balita Penderita Pneumonia Di RSUD Kota Bogor Tahun 2017

\begin{tabular}{lcc}
\hline \multicolumn{1}{c}{ Lama Rawat Inap } & n & \% \\
\hline 1-5 Hari & 51 & 66,2 \\
Lebih dari 5 Hari & 26 & 33,8 \\
Total & $\mathbf{7 7}$ & $\mathbf{1 0 0}$ \\
\hline
\end{tabular}

Sumber : Data Sekunder,2019

Berdasarkan Tabel 3, lama rawat inap pasien terbanyak adalah antara $1-5$ hari $(66,2 \%)$. Cara menghitung lama rawat inap adalah selisih antara tanggal pulang dengan tanggal masuk. Banyaknya pasien dengan lama rawat 
Putri NL: Evaluasi Rasionalitas Penggunaan...

inap berkisar 1-5 hari ini sesuai dengan penelitian Rahayu dkk dimana sebagian besar pasien rawat inap anak penderita pneumonia dirawat selama 3-5 (48\%) dan terdapat hubungan antara lama rawat inap dengan penggunaan antibiotik. ${ }^{7}$

Tabel 4. Distribusi Regimen dan Kategori Antibiotik pada Pasien Rawat Inap Balita Penderita Pneumonia Di RSUD Kota Bogor Tahun 2017

\begin{tabular}{|c|c|c|c|c|c|c|c|c|}
\hline \multirow[t]{2}{*}{ Regimen } & \multicolumn{7}{|c|}{ Kategori Gyssens } & \multirow[t]{2}{*}{ Total } \\
\hline & $\mathbf{0}$ & I & $\mathbf{I I}(\mathbf{A})$ & III(B) & IV $(\mathrm{C})$ & $\mathbf{V}$ & VI & \\
\hline Sefiksim & 0 & 0 & 1 & 0 & 0 & 0 & 0 & 1 \\
\hline Sefotaksim & 18 & 8 & 3 & 3 & 0 & 0 & 0 & 32 \\
\hline Seftazidin & 10 & 2 & 11 & 1 & 0 & 0 & 0 & 24 \\
\hline $\begin{array}{l}\text { Seftriakson } \\
\text { Sefotaksim\& }\end{array}$ & 6 & 0 & 2 & 0 & 0 & 0 & 0 & 8 \\
\hline $\begin{array}{l}\text { Eritromisin } \\
\text { Sefotaksim \& }\end{array}$ & 0 & 0 & 0 & 1 & 0 & 0 & 0 & 1 \\
\hline $\begin{array}{l}\text { Gentamisin } \\
\text { Sefotaksim \& }\end{array}$ & 5 & 0 & 2 & 1 & 0 & 0 & 0 & 8 \\
\hline Ampisilin & 1 & 0 & 2 & 0 & 0 & 0 & 0 & 3 \\
\hline Total & 40 & 10 & 21 & 6 & $\mathbf{0}$ & $\mathbf{0}$ & $\mathbf{0}$ & 77 \\
\hline
\end{tabular}

Sumber : Data Sekunder,2019

Berdasarkan Tabel 4 terdapat 7 jenis antibiotik yang digunakan (pemberian tunggal \& kombinasi). Terdiri dari ampisilin, sefiksim, sefotaksim, seftazidin, seftriakson, eritromisin, dan gentamisin. Dari semua regimen antibiotik, sebagian besar pasien diresepkan regimen antibiotik sefotaksim sebanyak 32 penggunaan. Menurut British Thoracic Society Tahun 2011, sefotaksim merupakan salah satu pilihan regimen antibiotik yang dianjurkan untuk diberikan kepada pasien rawat inap balita penderita pneumonia, selain amoksisilin, ko-amoksiklav, seftriakson, dan sefuroksim. Sefotaksim merupakan salah satu antibiotik golongan sefalosporin generasi ketiga yang direkomendasikan sebagai terapi empirik untuk infeksi yang disebabkan oleh pneumococci. Sefotaksim bersifat lebih aktif terhadap bakteri gram negatif dan pada Streptococcus pneumonia. Pemberian ampisilin pada pasien rawat inap balita penderita pneumonia juga sesuai dengan PIDS \& IDSA Guidelines yang merekomendasikan pemberian terapi empirik antibiotik spektrum sempit seperti ampisilin atau penisilin $G$ pada pasien pneumonia komunitas anak yang di rawat 
Putri NL: Evaluasi Rasionalitas Penggunaan...

inap. ${ }^{14}$ Pemberian jenis antibiotik lain seperti sefiksim, seftazidin, eritromisin, dan gentamisin pada pasien rawat inap balita penderita pneumonia di RSUD Kota Bogor Tahun 2017 juga sudah sesuai dengan pedoman tatalaksana pneumonia balita yang ditetapkan oleh IDAI 2008. Menurut pedoman tatalaksana pneumonia balita IDAI 2008, pemberian antibiotik pada pasien pneumonia yang dirawat inap, khususnya pada neonatus dan bayi kecil dapat diberikan antibiotik kombinasi betalaktam/klavulanat dengan aminoglikosid, atau sefalosporin generasi ketiga, atau dapat dikombinasikan dengan makrolid baru intravena terutama untuk pasien balita dan anak yang lebih besar. ${ }^{15}$

Pada penelitian ini tidak terdapat penggunaan antibiotik yang termasuk ke dalam kategori VI, V, IVC dikarenakan data pasien lengkap, antibiotik yang diberikan sudah sesuai indikasi, dan harga seluruh regimen antibiotik yang diberikan dinyatakan sama karena seluruh pasien balita pneumonia yang dirawat inap merupakan pasien BPJS. Dari semua regimen antibiotik yang telah dievaluasi dengan menggunakan pendekatan metode gyssens, sebagian besar penggunaan antibiotik rasional (0) yaitu sebanyak 40 penggunaan. Penggunaan antibiotik yang rasional menunjukkan bahwa penggunaan antibiotik pada pasien telah memenuhi seluruh kriteria gyssens. Penggunaan MK | Vol. 4 | No. 1 | OKTOBER 2020 antibiotik yang rasional akan memberikan optimalisasi terapi antibiotik sehingga luaran klinis yang dihasilkan juga optimal atau baik.

Pada penelitian ini, ditemukan sebanyak 37 penggunaan dari 77 total penggunaan antibiotik termasuk ke dalam kelompok penggunaan antibiotik tidak rasional, disebabkan oleh antara lain ketidaktepatan waktu pemberian (I) sebanyak 10 penggunaan, ketidaktepatan pemberian dosis antibiotik (IIA) sebanyak 21 penggunaan, dan pemberian antibiotik yang terlalu singkat (IIIB) sebanyak 6 penggunaan.

Ketidakrasionalan penggunaan antibiotik berikutnya berkaitan dengan pemilihan antibiotik berdasarkan waktu pemberian (I) yaitu sebanyak 10 penggunaan. Antibiotik yang termasuk kedalam kategori ini adalah sefotaksim, seftazidin. Pada penelitian ini, antibiotik sefotaksim dan seftazidin tidak diberikan setiap 8 jam sekali atau tidak sesuai dengan durasi waktu yang telah ditentukan oleh pedoman pemberian antibiotik untuk pasien balita penderita pneumonia. ${ }^{16}$

Ketidakrasionalan penggunaan antibiotik berikutnya berkaitan dengan dosis pemberian yang tidak tepat (IIA) yaitu sebanyak 21 penggunaan. Antibiotik yang termasuk kedalam kategori ini adalah sefiksim, kombinasi sefotaksim dan ampisilin, kombinasi sefotaksim dan 
Putri NL: Evaluasi Rasionalitas Penggunaan...

gentamisin, sefotaksim, seftazidin, dan seftriakson. Pada penelitian ini, pemberian dosis regimen antibiotik tidak sesuai dengan dosis yang telah ditentukan di dalam pedoman tatalaksana pneumonia pada balita. Dosis pemberian sefiksim yang seharusnya diberikan kepada pasien anak berusia 6 bulan atau lebih dengan berat badan kurang dari $45 \mathrm{~kg}$ yaitu 8 $\mathrm{mg} / \mathrm{kgBB} / \mathrm{hari}^{17} \quad$ Pemberian antibiotik kombinasi sefotaksim dan ampisilin juga ditemukan tidak sesuai dengan dosis yang telah diatur dalam formularium spesialistik IDAI 2013. Menurut Formularium Spesialistik IDAI 2013, dosis sefotaksim untuk dosis bayi dan anak sebesar 100-200 $\mathrm{mg} / \mathrm{kgBB} /$ hari setiap 6-8 jam untuk usia 1 bulan- 12 tahun dengan berat badan $<50 \mathrm{~kg}$ ; 1-2g setiap 6-8 jam untuk usia 1 bulan-12 tahun dan berat badan $>50 \mathrm{~kg} .{ }^{18}$ dan dosis ampisilin untuk bayi dan anak adalah sebesar $10-25 \mathrm{mg} / \mathrm{kgBB} /$ dosis setiap 6 jam. Dosis kombinasi sefotaksim dan gentamisin juga ditemukan tidak sesuai dengan dosis yang telah diatur dalam pedoman tatalaksana pneumonia balita.

Menurut pedoman tatalaksana pneumonia balita, dosis pemberian gentamisin pada neonatus dengan infeksi berat yaitu $5 \mathrm{mg} / \mathrm{kgBB} / \mathrm{hari}$ dibagi menjadi 2 dosis; 2-2,5 mg/kgBB setiap 8 jam untuk anak berusia 2 tahun keatas. ${ }^{17}$ Pemberian antibiotik seftazidin juga ditemukan tidak sesuai dengan formularium spesialistik MK | Vol. 4 | No. 1 | OKTOBER 2020
IDAI 2013. Menurut Formularium Spesialistik IDAI 2013, dosis seftazidin pada bayi yang berusia kurang dari 2 bulan yaitu sebesar 25-50 mg/kgBB/hari dalam 2 dosis, sedangkan untuk dosis pada bayi berusia lebih dari 2 bulan yaitu sebesar 50$100 \mathrm{mg} / \mathrm{kgBB} /$ hari dalam 2-3 dosis. ${ }^{19}$ Dosis antibiotik seftriakson juga ditemukan juga tidak sesuai dengan pedoman tatalaksana pneumonia balita.

Menurut Formularium Spesialistik IDAI 2013, dosis seftriakson pada bayi dan anak dapat diberikan secara intravena sebesar 20-50 mg/kgBB/hari. Dosis pemberian antibiotik pada balita ditentukan oleh berat badan. Ketidaktepatan pemberian dosis antibiotik, dapat menyebabkan terjadinya kegagalan terapi dan resistensi antibiotik. ${ }^{7}$

Ketidakrasionalan penggunaan antibiotik berikutnya berkaitan dengan pemberian antibiotik yang terlalu singkat (IIIB) yaitu sebanyak 6 penggunaan. Antibiotik yang termasuk kedalam kategori ini adalah kombinasi sefotaksim dan eritromisin, kombinasi sefotaksim dan gentamisin, sefotaksim, dan seftazidin. Lama pemberian antibiotik pada pasien balita penderita pneumonia berlangsung 37 hari. ${ }^{4}$ Berdasarkan Tabel 5, 51,9\% penggunaan antibiotik pada subyek bersifat rasional. Hal ini menunjukkan bahwa penggunaan antibiotik pada pasien telah memenuhi seluruh kriteria Gyssens. 
Putri NL: Evaluasi Rasionalitas Penggunaan...

Penggunaan antibiotik yang rasional akan memberikan optimalisasi terapi antibiotik sehingga luaran klinis yang dihasilkan juga optimal atau baik. 
Naifah Luthfiyah Putri : Evaluasi Rasionalitas Penggunaan...

Tabel 5. Distribusi Rasionalitas Penggunaan Antibiotik Pasien Rawat Inap Balita Penderita Pneumonia di RSUD Kota Bogor Tahun 2017

\begin{tabular}{lcc}
\hline \multicolumn{1}{c}{ Penggunaan Antibiotik } & n & \% \\
\hline Tidak Rasional & 37 & 48,1 \\
Rasional & 40 & 51,9 \\
Total & $\mathbf{7 7}$ & $\mathbf{1 0 0}$ \\
\hline
\end{tabular}

Sumber : Data Sekunder,2019

Tabel 6. Distribusi Luaran Klinis Pada Pasien Rawat Inap Balita Penderita Pneumonia di RSUD Kota Bogor Tahun 2017

\begin{tabular}{lcc}
\hline \multicolumn{1}{c}{ Luaran Klinis (Suhu) } & n & \% \\
\hline Tidak Normal & 36 & 46,8 \\
Normal & 41 & 53,2 \\
Total & $\mathbf{7 7}$ & $\mathbf{1 0 0}$ \\
\hline
\end{tabular}

Sumber : Data Sekunder,2019

Penggunaan suatu obat dikatakan rasional jika dampak negatif yang kemungkinan akan didapat lebih kecil daripada manfaat. Dampak negatif yang kemungkinan akan diterima pada penggunaan antibiotik tidak rasional adalah terjadinya efek samping, resistensi kuman, dan biaya pengobatan menjadi tidak terjangkau. ${ }^{4}$ Resistensi antibiotik dapat mengakibatkan perpanjangan penyakit, memanjangnya lama rawat inap, dan meningkatkan resiko kematian.

Pada penelitian ini, peneliti hanya melihat satu parameter luaran klinis yaitu suhu tubuh. Evaluasi luaran klinis pasien dilakukan setelah 48-72 jam pemberian antibiotik. Suhu tubuh dikatakan normal jika berkisar $36^{\circ} \mathrm{C}-37,5^{\circ} \mathrm{C}$, apabila suhu tubuh pasien berada diatas dari rentang tersebut dikatakan suhu tubuh pasien tidak normal atau pasien tidak mengalami perubahan luaran klinis setelah dilakukan pemberian antibiotik. ${ }^{7}$ Dari 77 pasien rawat inap balita penderita pneumonia di RSUD Kota Bogor Tahun 2017 yang memenuhi kriteria inklusi, sebagian besar luaran klinis normal (suhu tubuh kembali normal 48-72 jam pemberian antibiotik) sebesar 53,2\% (Tabel 6). Dalam pemberian antibiotik kepada pasien harus memperhatikan faktor farmakokinetik, karena data farmakokinetik sangat berguna untuk memperkirakan dosis antibiotik dan frekuensi pemberian yang tepat pada pasien. ${ }^{18}$ Farmakokinetik dan farmakodinamik suatu obat harus diperhatikan karena keduanya mempengaruhi kadar obat dalam darah dan efek terapi. Pasien yang diberikan antibiotik secara tepat (sesuai dengan farmakokinetik dan farmakodinamik) akan menghasilkan efek terapi yang baik berupa perbaikan luaran klinis, begitu pula sebaliknya. Selain ketepatan pemberian 
Naifah Luthfiyah Putri : Evaluasi Rasionalitas Penggunaan...

antibiotik, perbaikan luaran klinis juga dipengaruhi oleh resistensi antibiotik, kepatuhan dalam mengkonsumsi obat, dan reinfeksi. Jika terjadi salah satu hal diatas (terjadi resistensi antibiotik, kurangnya kepatuhan dalam mengkonsumsi obat, dan reinfeksi) akan menghasilkan luaran klinis yang tidak normal. ${ }^{19}$ Kondisi pasien (komplikasi) juga mempengaruhi luaran klinis pasien. Pasien yang mengalami komplikasi akan menghasilkan efek terapi yang kurang baik dan meningkatkan lama rawat inap pasien..$^{20}$

\section{Analisis Bivariat}

Berdasarkan Tabel 7, penggunaan antibiotik yang rasional menghasilkan luaran klinis (suhu) normal sebesar 75\%, sedangkan penggunaan antibiotik yang rasional menghasilkan luaran klinis (suhu) tidak normal sebesar 25\%. Pada penelitian ini, ditemukan terdapatnya hubungan antara penggunaan antibiotik dengan luaran klinis $(\mathrm{p}=0,000)$. Dengan terbuktinya hubungan antara penggunaan antibiotik dengan luaran klinis ini menandakan bahwa antibiotik empiris yang diberikan menurut pedoman tatalaksana pneumonia pada balita yang dirawat inap akan memberikan luaran klinis yang baik dikarenakan pedoman tatalaksana tersebut dibuat berdasarkan pola kuman dan telah mempertimbangkan farmakokinetik dan farmakodinamik. Terapi antibiotik secara empiris adalah terapi yang diberikan berdasarkan diagnosis klinis melalui pendekatan ilmiah. ${ }^{21}$

Tabel 7. Hubungan Penggunaan Antibiotik dengan Luaran Klinis

\begin{tabular}{lllll}
\hline \multicolumn{1}{c}{ Penggunaan Antibiotik } & \multicolumn{4}{c}{ Luaran Klinis (Suhu) } \\
& \multicolumn{1}{c}{$\mathbf{n}(\%)$} & \multicolumn{1}{c}{$\mathbf{n}(\%)$} & $\begin{array}{c}\text { Total } \\
(\%)\end{array}$ & Nilai p \\
\hline Tidak Rasional & $26(70,3)$ & $11(29,7)$ & $37(100)$ & 0,000 \\
Rasional & $10(25)$ & $30(75)$ & $40(100)$ & \\
\hline
\end{tabular}

Sumber : Data Sekunder,2019

Pemberian antibiotik yang rasional (tepat) dapat menghasilkan luaran klinis yang normal atau perbaikan luaran klinis dikarenakan antibiotik yang diberikan langsung bekerja pada agen penyebab atau menghambat bakteri penyebab pneumonia yang dapat menyebabkan terjadinya keluhan berupa demam. Perbaikan luaran klinis pasien pada kasus infeksi dipengaruhi oleh tiga aspek yang saling berhubungan satu sama lain, yaitu aspek antibiotik, aspek kuman, dan aspek penjamu. Aspek antibiotik meliputi farmakokinetik dan farmakodinamik suatu obat. Antibiotik diharapkan mampu mencapai lokasi infeksi dengan dosis yang 
Naifah Luthfiyah Putri : Evaluasi Rasionalitas Penggunaan...

cukup, penetrasi ke dalam sel bakteri, dan menganggu proses metabolisme bakteri sehingga bakteri penyebab infeksi menjadi tidak aktif atau mati, dan diharapkan tidak menimbulkan toksisitas yang berarti pada pasien. ${ }^{18}$ Dari segi aspek kuman meliputi jumlah konsentrasi dan daya sensitivitas kuman. Kedua hal tersebut merupakan faktor utama dalam keberhasilan terapi. Dari segi aspek penjamu meliputi status keadaan klinis pasien (sistem imun, derajat infeksi, status gizi, genetik, dan penyakit komorbid lainnya). ${ }^{21}$ Ketiga aspek tersebut sangat mempengaruhi luaran klinis pasien setelah dilakukan pemberian antibiotik. Jika terdapat salah satu dari tiga aspek diatas tidak terpenuhi, dapat menghasilkan luaran klinis yang kurang baik. Hal ini dibuktikan dengan hasil penelitian yang menunjukkan sebanyak $70,3 \%$ penggunaan antibiotik yang tidak rasional menghasilkan luaran klinis yang tidak normal (suhu tubuh tidak kembali normal).

\section{KESIMPULAN}

Berdasarkan hasil penelitian dapat disimpulkan bahwa penggunaan antibiotik secara rasional sebanyak $51,9 \%$ pasien memenuhi seluruh kriteria Gyssens. Penggunaan antibiotik rasional akan memberikan optimalisasi terapi sehingga luaran klinis yang dihasilkan baik. Terdapat hubungan antara penggunaan antibiotik dengan luaran klinis pada balita penderita pneumonia di RSUD Kota Bogor Tahun 2017.

\section{DAFTAR PUSTAKA}

1. Perhimpunan Dokter Paru Indonesia. Pneumonia komunitas Pedoman Diagnosis \& Penatalaksanaan Di Indonesia, Perhimpunan Dokter Paru Indonesia, Jakarta. 2014.

2. Kementerian Kesehatan R. Profil Kesehatan Indonesia Tahun 2016. Tersedia dari: Publikasi Kementerian Kesehatan RI. 2016.

3. Indonesia. Kementerian Kesehatan RI. Riset Kesehatan Dasar 2013, Kementerian Kesehatan RI, Jakarta. 2013

4. Peraturan Menteri Kesehatan. Peraturan Menteri Kesehatan Republik Indonesia Nomor 2406/MENKES/PER/XII/2011

Tentang Pedoman Umum Penggunaan Antibiotik, Jakarta.2011

5. Katarnida, SS, Murniati, D, Katar, Y. Evaluasi Penggunaan Antibiotik Secara Kualitatif di RS Penyakit Infeksi Sulianti Saroso, Jakarta, Sari Pediatri, Vol. 15, no. 6. 2014. 369-76.

6. Rahayu, YD, Wahyono, Djoko, M. Evaluasi Rasionalitas Penggunaan Antibiotik Terhadap Luaran Pada Pasien Anak Penderita Pneumonia, Tesis Program Pasca Sarjana Ilmu 
Naifah Luthfiyah Putri : Evaluasi Rasionalitas Penggunaan...

Farmasi, Universitas Gadjah Mada Yogyakarta. 2014 , diakses 19 April 2018

7. Aprillian, RI. Evaluasi Penggunaan Antibiotik Pada Pasien Anak Dengan Pneumonia Di Instalasi Rawat Inap RSUD Banyumas, Skripsi Program Studi Farmasi, Universitas Muhammad Purwokerto. 2014. diakses pada $27 \mathrm{Mei}$ 2018.

8. Aryani, DE, Hasmono, D, Zairina, N, Setiawan, L. Analysis of Antibiotics Use In Pediatric Pneumonia Patients Aged 3 Months 5 Years ${ }^{\text {ee }}$, Folia Medica Indonesiana, Vol. 52, no. 2. $2016 ; 108-15$

9. KEMENKES RI. Profil Kesehatan Indonesia Tahun 2016. Tersedia dari : Publikasi Kementerian Kesehatan RI. 2016

10. Yanti, YE. Rasionalitas Penggunaan Antibiotik Pada Pasien Rawat Inap Balita Penderita Pneumonia Dengan Pendekatan Metode Gyssens Di RSUD Sultan Syarif Mohamad Alkadrie Pontianak, Skripsi Program Studi Farmasi, Universitas Tanjungpura Pontianak. 2016. diakses pada 18 Februari 2019.

11. Hardanti, RD. Evaluasi Pengobatan Penyakit Pneumonia Pada Pasien Balita Dengan Pendekatan Manajemen Terpadu Balita Sakit (MTBS) Di
Puskesmas Kapuas Kabupaten Sanggau, Skripsi Program Studi Farmasi, Universitas Tanjungpura Pontianak. 2015. diakses pada 20 April 2018.

12. Fikri,BA. Analisis Faktor Risiko Pemberian ASI dan Ventilasi Kamar Terhadap Kejadian Pneumonia Balita, The Indonesian Journal of Public Health, Vol. 11(1), 2016. 1427.

13. Queen, MA, Myers, AL, Hall, M, Shah, SS, Williams, DJ, Auger, KA, Jerardi, KE, Statile, AM,Tieder, JS. Comparative Effectiveness of Empiric Antibiotics for Community Acquired Pneumonia ${ }^{e e}$, Pediatrics, Volume 133, No $1.2014: 24$

14. Said, M. Buku Ajar Respirologi Anak. Edisi Pertama, IDAI, Jakarta. 2008

15. Ikatan Dokter Anak Indonesia. FormulariumSpesialistik Ilmu Kesehatan Anak Ikatan Dokter Anak Indonesia, Ikatan Dokter Anak Indonesia, Jakarta. 2013. diakses 22 Januari 2019.

16. MacDougall, C, Goodman \& Gilman's The Pharmacological Basic of Therapeutics, Mc Graw Hill Education Lange, California.2017

17. Nugroho, B, Hadi, U.

Farmakokinetik \&

Farmakodinamik Terapi 
Naifah Luthfiyah Putri : Evaluasi Rasionalitas Penggunaan...

Antibiotik $^{\text {ee }}$. 2006. hlm. 2, diakses pada 27 Maret 2019.

18. Atharini, YH, Probosuseno, Nugroho, AE. Pola Pengobatan dan Luaran Klinis Pada Pasien Terinfeksi Helicobacter Pylorie, Jurnal Manajemen dan Pelayanan Farmasi, Vol. 6, no. 2, $2016:$ 156-157, diakses pada 11 Maret 2019

19. Ariani, PEA. Pengaruh Ketepatan Terapi Antibiotik Empiris Pada Komplikasi Infeksi Saluran Kemih Terhadap Prognosis Klinis Pasien Stroke Iskemik, Skripsi Program Studi Farmasi, Universitas
Sanata Dharma, Yogyakarta, 2018. diakses pada 26 Maret 2019.

20. Suardi, HN. Antibiotik Dalam Dunia Kedokteran Gigiee, Cakradonya Dent J, Vol. 6, no. 2. 2014 : 678-744,diakses27 Maret 2019

21. Muhajir, AS, Purwono, PB, Handayani. Gambaran Terapi dan Luaran Infeksi Saluran Kemih oleh Bakteri Penghasiil Extended Spectrum Beta Lactamase Pada Anak di RSUD Dr. Soetomo Surabayae, Sari Pediatri, Vol. 18, no. 2. 2016 : 111-116, diakses pada 27 Maret 2019. 